\section{Insecticidal Efficacy of Conventional and Botanical Insecticides against Potato Tuber Moth (Phthorimaea operculella (Zeller) Lepidoptera: Gelechiidae)}

\section{Pervin Erdogan ${ }^{1 *}$ and Errol Hassan ${ }^{2}$ \\ ${ }^{1}$ Department of Plant Protection, Plant Protection Central Re- search Institute, Ankara, Turkey}

${ }^{2}$ Department of Entomology, The University of Queensland, Gatton, Australia

\begin{abstract}
Potato Tuber Moth (PTM), Phthorimaea operculella Zeller (Lepidoptera: Gelechiidae), is an important pest of potato. It is common that there is in most countries where potatoes are grown. The chemical insecticides are used to control PTM. Because of chemical adverse effect, there is need to find safe alternative to chemical insecticides. For this porpoise, the effect of two botanical insecticides and two new pesticides were investigated on PTM. The effects of three different conventional and two different botanical insecticides against potato tuber moth larvae were investigated under laboratory conditions. The insecticides evaluated were: indoxacarb $150 \mathrm{~g} / \mathrm{L}$; spinetoram $120 \mathrm{~g} / \mathrm{L}$; deltamethrin $2.5 \mathrm{~g} / \mathrm{L}$; Gamma-T-ol as $75 \%$ terpene and Fungatol as terpinen-4-ol. The two botanical insecticides evaluated are major components of tea tree oil extracted from the tea tree Melaleuca alternifolia (Maiden \& Betche Myrtaceae) by distillation. The chemicals were sprayed

*Corresponding author: Pervin Erdogan, Department of Plant Protection, Plant Protection Central Research Institute, Ankara, Turkey, Tel: +90 3123445994; Fax: +90 3123151531; E-mail: pervin.erdogan@tarim.gov.tr
\end{abstract}

Citation: Erdogan E, Hassan E (2018) Insecticidal Efficacy of Conventional and Botanical Insecticides against Potato Tuber Moth (Phthorimaea operculella (Zeller) Lepidoptera: Gelechiidae). J Agron Agri Sci 1: 004.

Received: July 21, 2018; Accepted: November 15, 2018; Published: November 30, 2018

Copyright: (c) 2018 Erdogan E and Hassan E. This is an open-access article distributed under the terms of the Creative Commons Attribution License, which permits unrestricted use, distribution, and reproduction in any medium, provided the original author and source are credited. on potato tubers in insect cages before adult potato tuber moths were introduced. Three dose rates were used of each insecticide. Experiments were carried out as randomised block design and replicated four times plus an untreated control. The data of new larval establishment were collected weekly. It was determined that all of the doses of indoxacarb were effective in controlling the potato tuber moth for up to 112 days. All three doses of spinetoram and Gamma-T-ol (Tea tree oil $75 \%$ terpene) were effective up to 22 days. However, higher rates were effective up to 42 days. Both Fungatol (Tea tree oil terpinen-4-ol) and deltamethrin showed low effect. The aim of this paper was to determine by laboratory bioassays, the larvicidal activity of conventional and botanical insecticides against the larvae of the potato tuber moth.

Keywords: Conventional insecticides; Efficacy; Extracts; Potato tuber moth; Tea tree oil

\section{Introduction}

Potato Tuber Moth (PTM), Phthorimaea operculella Zeller (Lepidoptera: Gelechiidae) is a serious major insect pest of potatoes worldwide. It feeds on many Solanaceae, including crops such as potatoes, tomatoes, tobacco, egg plants and some ornamental and wild plants [1].

Potato tuber moth mature adult females produce 80 to 120 eggs or more, depositing them on potato foliage, or on the tubers, usually on the buds (eyes). The eggs are laid singly or in batches. Larvae feed on leaves, stems, petioles and, more importantly, on potato tubers in the field and in storage. The newly hatched larvae create tunnels in leaves by feeding on internal leaf tissue while leaving the upper and lower epidermis of the leaf untouched. In general larvae prefer feeding on young foliage [2]. Typical damage results from larvae boring tunnels in tubers. Larvae depositing silk and frass make tubers unmarketable and unfit for human consumption. Severe infestations have resulted in yield and quality losses during storage when previously infested tubers were stored with undamaged tubers $[3,4]$. Foliar damage to the potato crop does not usually result in significant yield losses, but infestation of tubers reduces marketability. Losses in storage may be up to $100 \%$, especially in non-refrigerated storage. The greatest amount of tuber damage occurs immediately before harvest if the crop is left in the field prior to harvesting. Additional damage may occur in storage if conditions are not controlled properly [5-7].

Potato growing areas in Turkey have several insect pests that attack and damage potato crops during the growing season. Most important is the PTM, which severely affects the vegetative parts of the growing plants and developing tubers in the field due to cracking soils and in storage. Many potato growers in Turkey use cultural practices to control PTM. Using deep planting and good coverage of potato seeds with soil hilling of more than $10 \mathrm{~cm}$ helps prevent damage by adults and larvae. However, when the populations of PTM are too high this cultural control practice is not sufficient to control the pests. Recently growers have changed their cultivation practices. Instead of using machinery for hilling soil against plants they are using digging machinery in cultivation which does not effectively hill the soil to cover the exposed tubers. This change in cultivation practice caused 
an increase in the PTM population which increased potato plant damage and caused high yield losses [8]. According to Ali the greater depth of planting and the more frequent hilling-up significantly lowered the damage to tubers [9]. Although pesticide use is not advised against potato tuber moth, potato farmers use pesticides during both storage and field conditions to control this pest. Therefore, the use of pesticides has increased and caused an increased risk of residues on potato. To eliminate the negative effects of insecticides, researchers have conducted many studies to find an alternative to current insecticides used against potato tuber moth. For example, it was determined that granulo virus may be used to control potato tuber moth under field conditions $[10,11]$. Steven, et al., reported that Bacillus thuringiensis (Bt) spp. kurstaki and Granulo Virus (GV) were significantly effective in controlling potato tuber moth [12]. Gomaa and El-Nenaey found that the application of Virotecto or GV infected larvae more effectively controlled PTM infestation than Bt-based insecticides [13]. Additionally, researchers found that neem treatments afforded acceptable protection against PTM in storage for many months and neem oil was as effective as the insecticide [14-16]. In addition, Abdel-Razek, et al., reported that application with neem formulation could effectively reduce the $P$. operculella population [17]. I recent, some plant extract. Recently, the extract obtained from tea tree oil [Leptospermum petersonii (FM Bailey) (Lemon Scented Oil: (LSO)], Melaleuca alternifolia L. (Myrtaceae)] were used as bio insecticides to control insects. There are many of studies about this subject. For example, Purwatiningshi, et al., found that the extracts $L$. petersonii had high effect on diamondback moth [18]. [Plutella xylostella L. (Lepidoptera: Plutellidae)]. It was concluded the extract of $L$. petersonii caused $100 \%$ mortality of the two-spotted spider mite (Tetranyhchus urticae) Koch (Acari:Tetranychidae) [19]. Also Kasap, et al., revealed that the extracts obtained from $M$. alternifolia caused high mortality of cotton aphid [Aphis gossypii Glover (Hemiptera:Aphididae)] [20].

The objective of this study was to determine the insecticidal effect of three conventional and two botanical products on PTM.

\section{Materials and Methods}

\section{Essential oils and synthetic insecticides}

In these experiments two components of tea tree oil: Gamma-T-ol $75 \%$ terpene; and a formulation called Fungatol whose main component is terpinen-4-ol were used. Local companies supplied the synthetic insecticides which are registered for use in PTM control. Avaunt (indoxacarb 150g/L EC), Radiant (spinetoram 120g/L SC) and Decis (deltamethrin $2.5 \mathrm{~g} / \mathrm{L}$ ) were used. Deltamethrin was used as a positive control in addition to a normal (untreated) control in the experiments.

\section{Insect cultures and rearing conditions}

Potato tuber moth adults were collected from potato fields at the Central Anatolian Province of Afyonkarahisar and transported to the Plant Protection Central Research Institute Laboratory, Ankara, Turkey. The adults were transferred to one litre size glass jars and provided with a $10 \%$ sugar solution as a food source. The lid was removed and replaced with muslin. The adult females laid their eggs on the muslin. The environmental conditions in the laboratory were kept constant $\left(25 \pm 1^{\circ} \mathrm{C} ; 60 \pm 5 \%\right.$ relative humidity) and 12:12 light: dark photoperiod. Eggs were collected daily and transferred to similar jars containing several potato tubers for larval establishment under similar laboratory conditions. Larvae were reared on potato tubers using the method described by Mandour [21].

\section{Bioassays}

Experiments were carried out as a randomised block design and replicated four times plus an untreated control. Plastic trays were used $(40 \mathrm{~cm} \times 30 \mathrm{~cm} \times 5 \mathrm{~cm})$. These trays were divided into three equal sections using sturdy cardboard dividers. Each section in each tray had 10 tubers treated with one of the three concentrations of the insecticides. Potato tubers used in experiments were washed and dried before being sprayed. Each tuber was sprayed individually with a hand held sprayer. Table 1 shows the concentrations of the three doses. Untreated (control) tubers received the same procedure except that they were sprayed with water. After spraying the trays were placed in the insect cages $(1 \mathrm{~m} \times 1 \mathrm{~m} \times 1 \mathrm{~m})$. Each insect cage had four trays. The same procedure was used for the remaining insecticides. Each insect cage received 25 male and 25 female adults for egg laying on the treated tubers. As a food source for adults each cage had a $10 \%$ sugar water solution supplied using a small jar with a hole drilled in the lid. A dental wick was inserted into the solution with the top end protruding above the lid for feeding. After seven days (1 week) all tubers were checked for larval establishment (larvae boring tunnels into tubers, lining the tunnel with silk and pushing their frass out from the entry point). The data were collected weekly according to new larval establishment. Data were collected on days 7, 12, 22, 42, 72 and 112 (16 weeks). In this research the Marfona variety of potatoes (popular among the potato growers in Turkey) was used.

\begin{tabular}{|c|c|c|}
\hline $\begin{array}{c}\text { Active ingredient } \\
\text { and rate }\end{array}$ & $\begin{array}{c}\text { Recommendation Dose } \\
\mathbf{( m l} / \mathbf{L})\end{array}$ & Application Dose (mI/L) \\
\hline Indoxacarb $150 \mathrm{~g} / \mathrm{L} \mathrm{EC}$ & $10,15,25 / 100$ & $0.10,0.15,0.25$ \\
\hline Spinetoram $120 \mathrm{~g} / \mathrm{L} \mathrm{SC}$ & $10,15,25 / 50$ & $0.20,0.30,0.50$ \\
\hline Gamma-T-ol & $2.5-3.5-5 / \mathrm{L}$ & $2.5,3.5$ \\
\hline Fungatol & $2.5-3.5-5 / \mathrm{L}$ & $2.5,3.5,5$ \\
\hline Deltamethrin $2.5 \mathrm{~g} / \mathrm{L}$ & $15-20-30 / 50$ & $0.30,0.40,0.60$ \\
\hline
\end{tabular}

Table 1: Insecticides and plant extracts used in this study.

\section{Statistical analysis}

Effects of the insecticides were calculated according to Abbott as follows [22]:

Where;

$\mathrm{x}=$ effect

$a=$ number of infestation tuber in treatment

$\mathrm{b}=$ number of infestation tuber in control

The obtained results were submitted to variance analyses and the mean values compared by Duncan's test. Significant differences $(\mathrm{p}=0.05)$ were calculated by the program: SPSS 20.6.

\section{Results and Discussion}

Data (Table 2) showed that all of the doses of indoxacarb were statistically superior to control (100\% tuber infestation) in preventing damage to potato tubers by PTM. Amongst the treatments indoxacarb was the most effective (each with an average of per cent tuber infestation). Only two doses of Gama-T-ol and spinetoram had $0 \%$ infestation up to 22 days it was noticed that Fungatol and deltamethrin had the highest infestation rate. 
Citation: Erdogan E, Hassan E (2018) Insecticidal Efficacy of Conventional and Botanical Insecticides against Potato Tuber Moth (Phthorimaea operculella (Zeller) Lepidoptera: Gelechiidae). J Agron Agri Sci 1: 004.

\begin{tabular}{|c|c|c|c|c|c|c|c|c|c|c|c|c|c|}
\hline \multirow{2}{*}{ Treatments } & \multirow{2}{*}{$\begin{array}{l}\text { Doses } \\
(\mathrm{ml} / \mathrm{L})\end{array}$} & \multicolumn{2}{|c|}{7 days } & \multicolumn{2}{|c|}{12 days } & \multicolumn{2}{|c|}{22 days } & \multicolumn{2}{|c|}{42 days } & \multicolumn{2}{|c|}{72 days } & \multicolumn{2}{|c|}{112 days } \\
\hline & & $\operatorname{Ir}(\%)$ & E (\%) & $\operatorname{Ir}(\%)$ & E (\%) & $\operatorname{Ir}(\%)$ & E (\%) & $\operatorname{Ir}(\%)$ & E (\%) & $\operatorname{Ir}(\%)$ & E (\%) & $\operatorname{Ir}(\%)$ & E (\%) \\
\hline \multirow{3}{*}{ Indoxacarb } & 0.10 & 0 & $100 \pm 0 \mathrm{a}$ & $0 \pm 0 \mathrm{a}$ & $100 \pm 0 \mathrm{a}$ & $0 \pm 0 \mathrm{a}$ & $100 \pm 0 \mathrm{a}$ & $0 \pm 0 \mathrm{a}$ & $100 \pm 0 \mathrm{a}$ & $0 \pm 0 \mathrm{a}$ & $100 \pm 0 \mathrm{a}$ & $0.00 \pm 0 \mathrm{a}$ & $100 \pm 0 \mathrm{a}$ \\
\hline & 0.15 & 0 & $100 \pm 0 \mathrm{a}$ & $0 \pm 0 \mathrm{a}$ & $100 \pm 0 \mathrm{a}$ & $0 \pm 0 \mathrm{a}$ & $100 \pm 0 \mathrm{a}$ & $0 \pm 0 \mathrm{a}$ & $100 \pm 0 \mathrm{a}$ & $0 \pm 0 \mathrm{a}$ & $100 \pm 0 \mathrm{a}$ & $0.00 \pm 0 \mathrm{a}$ & $100 \pm 0 \mathrm{a}$ \\
\hline & 0.25 & 0 & $100 \pm 0 \mathrm{a}$ & $0 \pm 0 \mathrm{a}$ & $100 \pm 0 \mathrm{a}$ & $0 \pm 0 \mathrm{a}$ & $100 \pm 0 \mathrm{a}$ & $0 \pm 0 \mathrm{a}$ & $100 \pm 0 \mathrm{a}$ & $0 \pm 0 \mathrm{a}$ & $100 \pm 0 \mathrm{a}$ & $0.00 \pm \mathrm{a}$ & $100 \pm 0 \mathrm{a}$ \\
\hline \multirow{3}{*}{ Spinetoram } & 0.20 & 0 & $100 \pm 0 \mathrm{a}$ & $0 \pm 0 \mathrm{a}$ & $100 \pm 0 \mathrm{a}$ & $0 \pm 0 \mathrm{a}$ & $100 \pm 0 \mathrm{a}$ & $37.5 \pm 8.53 b$ & $62.5 \pm 0 \mathrm{~b}$ & $100 \pm 0 \mathrm{~b}$ & $0 \pm 0 \mathrm{a}$ & $100 \pm 0 \mathrm{~b}$ & $0 \pm 0 \mathrm{~b}$ \\
\hline & 0.30 & 0 & $100 \pm 0 \mathrm{a}$ & $0 \pm 0 \mathrm{a}$ & $100 \pm 0 \mathrm{a}$ & $0 \pm 0 \mathrm{a}$ & $100 \pm 0 \mathrm{a}$ & $0 \pm 0 \mathrm{a}$ & $100 \pm 0 \mathrm{a}$ & $100 \pm 0 \mathrm{~b}$ & $22.5 \pm 4.78 b$ & $100 \pm 0 \mathrm{~b}$ & $0 \pm 0 \mathrm{~b}$ \\
\hline & 0.50 & 0 & $100 \pm 0 \mathrm{a}$ & $0 \pm 0 \mathrm{a}$ & $100 \pm 0 \mathrm{a}$ & $0 \pm 0 \mathrm{a}$ & $100 \pm 0 \mathrm{a}$ & $0 \pm 0 \mathrm{a}$ & $100 \pm 0 \mathrm{a}$ & $100 \pm 0 \mathrm{~b}$ & $27.5 \pm 7.5 \mathrm{~b}$ & $100 \pm 0 \mathrm{~b}$ & $0 \pm 0 \mathrm{~b}$ \\
\hline \multirow{3}{*}{$\underset{\text { T-ol }}{\text { Gamma- }}$} & 2.50 & 0 & $100 \pm 0 \mathrm{a}$ & $0 \pm 0 \mathrm{a}$ & $100 \pm 0 \mathrm{a}$ & $0 \pm 0 \mathrm{a}$ & $100 \pm 0 \mathrm{a}$ & $32 \pm 4.78 \mathrm{~b}$ & $67.5 \pm 6.29 b$ & $100 \pm 0 \mathrm{~b}$ & $0 \pm 0 \mathrm{a}$ & $100 \pm 0 \mathrm{~b}$ & $0 \pm 0 \mathrm{~b}$ \\
\hline & 3.50 & 0 & $100 \pm 0 \mathrm{a}$ & $0 \pm 0 \mathrm{a}$ & $100 \pm 0 \mathrm{a}$ & $0 \pm 0 \mathrm{a}$ & $100 \pm 0 \mathrm{a}$ & $0 \pm 0 \mathrm{a}$ & $100 \pm 0 \mathrm{a}$ & $100 \pm 0 \mathrm{~b}$ & $22.5 \pm 4.78 b$ & $100 \pm 0 \mathrm{~b}$ & $0 \pm 0 \mathrm{~b}$ \\
\hline & 5.00 & 0 & $100 \pm 0 \mathrm{a}$ & $0 \pm 0 \mathrm{a}$ & $100 \pm 0 \mathrm{a}$ & $0 \pm 0 \mathrm{a}$ & $100 \pm 0 \mathrm{a}$ & $0 \pm 0 \mathrm{a}$ & $100 \pm 0 \mathrm{a}$ & $100 \pm 0 \mathrm{~b}$ & $25 \pm 6.45 \mathrm{c}$ & $100 \pm 0 \mathrm{~b}$ & $0 \pm 0 \mathrm{~b}$ \\
\hline \multirow{3}{*}{ Fungatol } & 2.50 & 0 & $85 \pm 2.88 \mathrm{a}$ & $15 \pm 2.88 \mathrm{~d}$ & $47.5 \pm 7.5 b c$ & $42.5 \pm 6.29 b$ & $42.5 \pm 6.24 \mathrm{c}$ & $100 \pm 0 \mathrm{c}$ & $0 \pm 0 \mathrm{c}$ & $100 \pm 0 \mathrm{~b}$ & $0 . \pm 0 \mathrm{~d}$ & $100 \pm 0 \mathrm{~b}$ & $0 \pm 0 \mathrm{~b}$ \\
\hline & 3.50 & 0 & $75 \pm 2.88 \mathrm{~b}$ & $25 \pm 2.88 \mathrm{~d}$ & $57.5 \pm 12.5 b$ & $42.5 \pm 4.78 b$ & $57.5 \pm 12.5 b$ & $100 \pm 0 \mathrm{c}$ & $0 \pm 0 \mathrm{c}$ & $100 \pm 0 \mathrm{~b}$ & $0 \pm 0 \mathrm{~d}$ & $100 \pm 0 \mathrm{~b}$ & $0 \pm 0 \mathrm{~b}$ \\
\hline & 5.00 & 0 & $70 \pm 4.08 \mathrm{~b}$ & $30 \pm 4.08 \mathrm{bc}$ & $50 \pm 5.25 b$ & $50.0 \pm 4.56 \mathrm{c}$ & $22.5 \pm 5.5 \mathrm{~d}$ & $100 \pm 0 \mathrm{c}$ & $0 \pm 0 \mathrm{c}$ & $100 \pm 0 \mathrm{~b}$ & $0 \pm 0 \mathrm{~d}$ & $100 \pm 0 \mathrm{~b}$ & $0 \pm 0 \mathrm{~b}$ \\
\hline \multirow{2}{*}{$\begin{array}{c}\text { Deltame- } \\
\text { thrin }\end{array}$} & 0.40 & 0 & $55 \pm 8.66 \mathrm{c}$ & $30 \pm 4.08 \mathrm{bc}$ & $42.5 \pm 6.24 \mathrm{c}$ & $57.5 \pm 12.5 \mathrm{c}$ & $22.5 \pm 6.29 \mathrm{~d}$ & $100 \pm 0 \mathrm{c}$ & $0 \pm 0 \mathrm{c}$ & $100 \pm 0 \mathrm{~b}$ & $0 \pm 0 \mathrm{~d}$ & $100 \pm 0 \mathrm{~b}$ & $0 \pm 0 \mathrm{~b}$ \\
\hline & 0.60 & 0 & $82 \pm 2.5 \mathrm{ab}$ & $17 \pm 2.50 \mathrm{~d}$ & $37.5 \pm 8.55 \mathrm{~d}$ & $62 . \pm 6.29 \mathrm{c}$ & $17.50 \pm 4.78 \mathrm{~d}$ & $100 \pm 0 \mathrm{c}$ & $0 \pm 0 \mathrm{c}$ & $100 \pm 0 \mathrm{~b}$ & $0 \pm 0 \mathrm{~d}$ & $100 \pm 0 \mathrm{~b}$ & $0 \pm 0 \mathrm{~b}$ \\
\hline \multicolumn{2}{|c|}{ Control } & 0 & & $45 \pm 8.66 \mathrm{~b}$ & & $75.0 \pm 6.45 \mathrm{~d}$ & & $100 \pm 0 \mathrm{c}$ & & $100 \pm 0 \mathrm{~b}$ & & $100 \pm 0 \mathrm{~b}$ & \\
\hline
\end{tabular}

Table 2: Percentage of tubers infested and effectiveness of insecticides in preventing infestation by PTM (\%) (Mean \pm SE)*.

*Within columns, means $\pm \mathrm{SE}$ followed by the same letter are not significantly different (DUNCAN's multiple F-test), IR: Infestation rate, E: Effect

As shown in table 2, the tested products indoxacarb, spinetoram and Gamma-T-ol were 100 percent effective up to 7 days of treatment and were significantly superior even after 72 days of the treatment with an average infestation of $37.5 \%$ as compared to control $(100 \%)$. It was determined that two concentrations ( 15 and $20 \mathrm{ml})$ of spinetoram were effective in preventing the damage to potato tubers by PTM during 42 days. It was revealed that the lowest doses of spinetoram protected tubers for 35 days under laboratory conditions. Similarly, it was determined that the second and third doses of Gama-t-ol were effective in prevented the damage to potato tubers for 42 days. The data suggested that Fungatol and deltamethrin offered no protection to tubers against PTM. The treatments of Fungatol, deltamethrin and control obtained similar efficacy results. Indoxacarb treated tubers had no sign of infestation after 112 days. In addition, spinetoram and Gamma-t-ol treated tubers had no sign of infestation after 42 days but there were $27.5 \%$ and $22.5 \%$ damage respectively after 49 days. This is in contrast to Fungatol and deltamethrin treated tubers, which offered no protection and infestations were similar to that of the control.

The results show that the medium and high doses of Gamma-T-ol treated tubers had no sign of infestation and prevented damage to potato tubers by PTM for 42 days. All of doses Fungatol treated tubers had infestation at after seven days and not effective. The Gamma-T-ol and Fungatol are new extracts which have been tested against a few insect pests before. Only there was a study on effect of PTM. The effect of extract $L$. petersonii on larva of PTM was investigated. In this study, the highest mortality $(100 \%)$ occurred at concentration of $0.4 \%$ while the smallest mortality was at $0.05 \%$ the extracts of $L$. petersonii [23]. There are references of using an extract of $L$. petersonii against other insects. For example, the efficacy of LSO against the diamondback moth P. xylostella L. was evaluated. According to this study the feeding activity and development were significantly reduced of larval stages on broccoli leaves that had been dipped in LSO.
Oviposition deterrence was also found when an adult stage was exposed to treated leaves. Fecundity dropped by $50 \%$ at concentrations of $0.5 \%$. The $\mathrm{LC}_{50}$ value for third instar larvae was estimated to be $2.93 \%$ at 7 days after treatment. In addition, the oil was also tested at concentrations from 0.5 to $6 \%$ for oviposition deterrence of an egg parasitoid of the diamondback moth, Trichogramma pretiosum (Riley) (Hymenoptera: Trichogrammatidae). LSO deterred parasitisation in choice tests but not in no-choice tests. LSO did not cause mortality of $T$. pretiosum during 24 hours in a contact toxicity test.

It was concluded that LSO had no significant effects on the parasitoid, and therefore LSO is compatible with this biocontrol agent for integrated management of the diamondback moth [18]. Similarly, Erdogan and Hassan [19] revealed that the extract of L. petersonii caused $100 \%$ mortality of the two-spotted spider mite at 6 days after treatment.

Little is known about the effects of Fungatol (tea tree terpinen-4-ol) and Gamma-T-ol (tea tree oil, 75\% Terpene) obtained from the tea tree on insects. Studies on the effect of Fungatol and gamma on insects are limited. The first study the effects of Fungatol and Gamma-T-ol was carried out by Iramu [24]. In this study, the insecticide effect of Fungatol, Gamma-T-ol, Fungatol + Neem and Gamma-T-ol + Neem extracts on A. gossypii was investigated in laboratory conditions. The leaf disc dipping method was used in laboratory tests. The highest insecticidal effect showed Fungatol + Neem and Gamma-T-ol + Neem extracts on A. gossypii. In addition, it has been reported that these extracts have no effect on the reproduction and development of A. gossypii. In another study, researchers have reported that Fungatol + Neem spray (50.0-001) had the highest efficacy on T. absoluta. Kasap, et al., investigated the toxic effects of Fungatol and GammaT-ol extracts on A. gossypii and T. urticae under laboratory conditions $[25,20]$. The researchers reported that extracts of Fungatol (3.50\%) and Gamma-T-ol (3.60\%) resulted in $42 \%$ and $48.9 \%$ of mortality, 
respectively, after 48 hours on $A$. gossypii because of their different concentrations of extracts. The same concentrations of extracts were reported to cause $94 \%$ and $93.3 \%$ of mortality on T. urticae adult females after 72 hours. Kok and Kasap found that the effects of insecticides on Myzus persicae Sulzer, (Hem: Aphididae) which cause economic losses in many cultivated plants under laboratory conditions in the same extracts [26]. They reported that extracts of Fungatol $(3,50 \%)$ and Gamma-T-ol $(3,60 \%)$ resulted in $72 \%$ and $80 \%$ mortality treatment after 72 hours on $M$. persicae respectively. Gamma-T-ol and Fungatol have been used against other arthropods. For example, it was revealed that the highest mortalities were observed at concentrations of $3.5 \%$ of Fungatol and $3.6 \%$ of Gamma-T-ol, and the mortalities caused by 3.5 and $3.6 \%$ concentrations of Fungatol and Gamma-T-ol, respectively, at 1, 24, 48 and 72 hours, were 0, 52, $74,94 \%, 0,52,78$ and $94 \%$ on two spotted mite respectively [27]. In addition, Kasap, et al., revealed that after 1, 24 and $48 \mathrm{~h}$, the highest concentration of Fungatol (3.5\%) and Gamma-T-ol (3.6\%) obtained from $M$. alternifolia had caused $0,18,42 \%$ and $0,20,48.9 \%$ mortality of cotton aphid respectively. moreover, Fungatol and Gamma-T-ol showed the high repellent effect against $T$. urticae under laboratory conditions [20,28].

There are many studies the insecticidal about effect of plant extracts on PTM. For instance, Sharaby, et al., revealed that vapors of Cymbopogon citrates Stapf., Myristica fragrans Houtt., Mentha citrate and a-l on one caused highly significant reductions in the life span of exposed PTM [29]. In another study, Treated potato tubers by methanolic extract of lavender elicited the lowest percentage of first larval PTM penetration, and studying of oviposition-preference demonstrated that the largest number of eggs was laid on control and fumitory with 28 and 10 eggs after three days, respectively [30]. Moreover, it was determined that dried powders of Allium cepa, Curcuma longa, Colocasia antigurum, Ocimum basilicum, Dodonaca viscose and Thuja orientalis played a highly significant role in reducing egg deposition on PTM [31]. Lal found that the leaves of Lantana aculeate provided most protection to the tubers, reducing damage than Eucalyptus globulus and Bacillus thurungiensis [32]. It was observed that extracts of Piper nigrum and Matricaria chamomile showed high mortality, anti feeding and repellent effect on larva of PTM [33].

Results from this laboratory testing showed that indoxacarb provide efficient control for 112 days. These results confirmed the data presented by Dobie who mentioned about a slower, but at the same time the most continuous, effect of indoxacarb against young larvae of the PTM compared with other tested compounds [34]. Gecheva and Dimitrov revealed that indoxacarb and deltamethrin caused $100 \%$ larvicidal mortality 14 days after treatment [35]. The same authors found that after indoxacarb and deltamethrin treatment ovicidal mortality was $38.8 \%$ and $49.6 \%$ respectively. Das and Rahman determined that deltamethrin (K-obiol DP2) treatment kept potato tubers free of the pest [36]. The best control over the PTM can be exercised by indoxacarb. In our experiments deltamethrin showed some effect on PTM as Das and Rahman revealed in their studies [36]. In Tunisia Das, et al., found that deltamethrin, granulosis virus and B. thuringienses were equally effective in reducing pest damage, and after 3 months storage the treatments showed no significant effect on sprouting [37]. Collantes, et al., who found that deltamethrin was most toxic for adult of PTM [38]. This may be explained that deltamethrin used in our experiments could be a different formulation.
According to our results, spinetoram (15 and $25 \mathrm{ml}$ ) have been found to be effective in preventing damage to potato tubers by PTM for up to 42 days. In parallel with our results, Dobi revealed that when larvae were exposed to spinetoram mortality increased directly with time of exposure [34]. Mortality was noticed quickly at the 5 minute mark with $10 \%$ mortality. This mortality more than doubled at the next time interval of 15 minutes. Between 15 minute and 30 minute intervals, the mortality rate had the highest increase from $28 \%$ to $72 \%$ mortality. The mortality rate then started to plateau between the 30 minute and the 60 minute interval. By 120 minutes, the evaluation timing, spinetoram had caused $100 \%$ mortality. In addition, it was determined that spinetoram was effective in controlling PTM in field conditions, which is in accordance with our results [39].

\section{Conclusion}

It was suggested that tubers sprayed with one of three doses $(10$, 15 , or $25 \mathrm{ml}$ ) of indoxacarb had no infestation by PTM over a 16 -week period. The two botanical insecticides (Gamma-T-ol and Fungatol), showed significant effect up to 22 days with the Gamma-T-ol extending into 42 days. Two dose rates of spinetoram (15 and $25 \mathrm{ml} / \mathrm{l})$ were effective on PTM for 42 days. More research is required to develop this initial study further.

\section{Acknowlegement}

The authors like to thank Ms. Sonya Fardell and Dr. John Dingle for their time for reading the manuscript and their input. The authors are grateful to Dr. Numan E. Babaroglu for statistical analysis in Plant Protection Central Institute Ankara-Turkey.

\section{References}

1. Rondon SI (2010) The Potato Tuberworm: A Literature Review of Its Biology, Ecology, and Control. Am J Pot Res 87: 149-166.

2. Triverdi TP, Rajagopal D (1992) Distribution, biology, ecology and management of potato tuber moth, Phthorimaea operculella (Zeller) (Lepidoptera: Gelechiidae): A review. Trop Pest Manage 38: 279-285.

3. Malakar-Kuenen R, Tingey WM (2006) Aspects of tuber resistance in hybrid potatoes to potato tuber worm. Entomol Exp Appl 120: 131-137.

4. Bacon OG, Calley N, Riley WD, James RH (1971) Evaluation of insecticides for control of the green aphid and tuberworm on Irish potatoes. American Potato Journal 48: 298.

5. Rondon SI, DeBano SJ, Clough GH, Hamm PH, Jensen A, et al. (2007) Biology and Management of the Potato Tuberworm in the Pacific Northwest. PNW 594: 1-8.

6. Von Arx R, Goueder J, Cheikh M, Temime AB (1987) Integrated control of potato tubermoth Phthorimaea operculella (Zeller) in Tunisia. Int J Trop Insect Sc 8: 989-994.

7. Mandour NS, Sarhan AA, Atwa DH (2012) The integration between Trichogramma evanescens West. (Hymenoptera: Trichogrammatidae) and selected bioinsecticides for controlling the potato tuber moth Phthorimaea operculella (Zell.) (Lepidoptera: Gelechiidae) of stored potatoes. Journal of Plant Protection Research 52: 41-46.

8. Erdogan P (2014) The importance of Potato tuber moth [Phthorimae operculella (Zeller) (Lepidoptera:Gelechiidae), the situation in our country and control. The Journal of Turkey Seed Growers Association 41-42.

9. Ali MA (1993) Effects of cultural practices on reducing field infestation of potato tuber moth (Phthorimaea operculella) and greening of tubers in the Sudan. J Agr Sci 121: 187-192. 
10. Salah HB, Aalbu R (1992) Field use of granulosis virus to reduce initial storage infestation of the potato tuber moth, Phthorimaea operculella (Zeller), in North Africa. Agr Ecosyst Environ. 38: 119-126.

11. Chandel RS, Chandla VK (2005) Integrated control of potato tuber moth (Phthorimaea operculella) in Himachal Pradesh. Indian J Agr Sci 75: 837 839.

12. Arthurs SP, Lacey LA, Pruneda JN, Rondon SI (2008) Semi-field evaluation of a granulovirus and Bacillus thuringiensis spp. kurstaki for season-long control of the Potato tuber moth, Phthorimaea operculella. Entomol Exp Appl 129: 276-285.

13. Gomaa AE, El-Nenaey HM (2006) Evaluation of certain controlling measures for Phthorimaea operculella (Zeller) (Lepidoptera, Gelechiidae) on potato in stores. The Egyptian Journal of Agricultural Research 84: 31-41.

14. Hossein SMZ, Das GP, Ala MZ 1994) Use of various indigenous materials and insecticides in controlling Potato tuber moth in storage. Bulletin of Institute of Tropical Agriculture Kyushu University 17: 79-84.

15. Debnath MC, Khound NJ, Dutta SK and Sarmah PC (1998) Managemen of Potato tuber moth, Phthorimaea operculella (Zeller) in potato storage. Journal of the Agricultural Science Society of North-East India 11: 55-60.

16. Salama HS, Salem SA (2000) Bacillus thuringiensis and neem seed oil (Azadirachta indica) effects on the potato tuber moth Phthorimaea operculella zeller in the field and stores. Arch Phytopathol Pfl 33: 73-80.

17. Abdel-Razek AS, Salem AE, Ghany NMB (2014) Sustainable Potato tuber moth Phthorimaea operculella (Zeller) control using biopesticides of natural and microbial origin. African Journal of Science and Technology 2: $125-130$.

18. Purwatiningshi P, Heather N, Hassan E (2012) Efficacy of Leptospermum petersonii oil, on Plutella xylostella, and its parasitoid, Trichogramma pretiosum. J Econ Entomol 105: 1379-1384.

19. Erdogan P, Hassan E (2014) The effects of plant extracts of lemon-scented tea tree [Leptospermum petersonii (Myrtaceae)] on Tetranychus urticae Koch (Acarina:Tetranychidae) International Conference on Biopesticides 7 (ICOB7). Antalya, Turkey.

20. Kasap I, Kok S, Hassan E (2016) Effect of Fungatol and Gamma-T-ol from Melaleuca alternifolia (Maiden \& Betche) Cheel on Aphis gossypii Glover (Hemiptera: Aphididae) and Tetranychus urticae Koch (Acari: Tetranychidae). Turkish Journal of Entomology 40: 117-123.

21. Mandour NS (1997) Ecological and biological studies on the polyembryonic parasitoid Copidosoma desantisi Annecke \& Mynhardt parasitic on the Potato tuber moth in Suez Canal area. M.Sc.Thesis, Faculty of Agriculture, Suez Canal Universtiy 9: 109-116.

22. Abbot WS (1925) A method of computing the effectiveness of an insecticide. Journal of Economic Entomology 18: 265-267.

23. Erdogan P, Hassan E ( 2017) Insecticidal Effectof Three Different Plant Extract On Potato tuber moth [Phthorimaea operculella Zeller (Lepidoptera .:Gelechiidae)]Central Anatolia Region 3. Agriculture and Food Congress. October, 26-28, Sivas, Turkey.

24. Iramu ET, George D, Hassan E (2011) Evaluation of the efficacy of essential oil formulations against aphid Aphis gossypii Glover (Hemiptera: Aphididae) on Abelmeschus manihot. International Conference on Biopesticides 6 (ICOB 6), Chang-Mai, Thailand.
25. Bayindir A, Ozger S, Karaca I, Birgucu AK, Hassan E (2014) Effects of biopesticides on Tuta absoluta (Lepidoptera:Gelechiidae) under laboratory conditions. International Conference on Biopesticides 7 (ICOB7) Antalya, Turkey.

26. Kok S, Kasap I (2016) Natural Insecticides Effects of Two Different Plant Extract on Green Peach Aphid, Myzus persicae Sulzer 1776 (Hemiptera Aphididae). Conscious Healthy Life Journal 12: 209-215.

27. Kasap I, Hassan E (2014) Effects of two different plant extracts on the two spotted spider mite Tetranychus urticae Koch (Acari:Tetranychidae). International Conference on Biopesticides 7 (ICOB 7) Antalya, Turkey.

28. Kok S, Erdoğmuş A, Koyun A, Kasap I (2016) Repellent Effect of Fungatol and Gamma-T-ol Extracts Derived from Melaleuca alternifolia (Myrtaceae) against Tetranychus urticae Koch (Acari: Tetranychidae) under Laboratory Conditions. COMU Journal Agriculture. Faculty 4: 93-98.

29. Sharaby A, Rahman HA, Abdel-Aziz SS, Moawad SS (2014) Natural Plan Oils and Terpenes as Protector for the Potato Tubers against Phthorimaea operculella Infestation by Different Application Methods. Ecologia Balkanica 6: 45-59.

30. Dastjerdi HF, Khorrami F, Razmjou J, Esmaielpour B, Golzadeh A, et al (2013) The efficacy of some medicinal plant extracts and essential oils against potato tuber moth, Phthorimaea operculella (Zeller) (Lepidoptera: Gelechiidae). Journal Crop Protection 2: 93-99.

31. Sharaby A, Abdel-Rahman H, Moawad S (2009) Biological effects of some natural and chemical compounds on the potato tuber moth, Phthorimaea operculella Zell. (Lepidoptera:Gelechiidae). Saudi J Biol Sci 16 : $1-9$.

32. Lal L (1987) Studies on natural repellents against potato tuber moth (Phthorimaea operculella Zeller) in country stores. Potato Research 30: 329-334.

33. Khatter NA (2010) Insecticidal Activity of Certain Plant Extracts Against Potato Tuber Moth Larvae of Phthorimaea operculella (Zeller). Egypt J Exp Biol (Zoo) 6: 347-355.

34. Dobi CH (2010) Pesticides susceptibility of potato tuberworm in the Pacific Northwest. Thesis of Master's degree. Washington State University, USA.

35. Gancheva VT, Dimitrov Y (2013) Chemical control of the Potato tuber moth Phthorimaea operculella (Zeller) on tobacco. Bulgarian Journal of Agricultural Science 19: 1003-1008.

36. Das GP, Rahman MM (1997) Effect of some inert materials and insecticides against the potato tuber moth, Phthorimaea operculella (Zeller), in storage. International Journal of Pest Management 43: 247-248.

37. Das GP, Langnaoui A, Salah HB, Souibgui M (1998) The control of the Potato tuber moth in storage in Tunisia. Tropical Science 38: 78-80.

38. Collantes LG, Raman KV, Cisneros FH (1986) Effect of six synthetic pyrethroids on two populations of potato tuber moth, Phthorimaea operculella (Zeller) (Lepidoptera: Gelechiidae), in Peru. Crop Protection 5: 355-357.

39. Erdogan P, Hassan E (2017) Determination of Time of Insecticide Application Against Potato Tuber Moth, Phthorimaea operculella Zeller (Lep: Gelechiidae) in the Field Conditions in Turkey. Canadian Journal of Pure and Applied Science 11: 4061-4066. 


\section{Hit \\ HERALD}

Journal of Anesthesia \& Clinical Care

Journal of Addiction \& Addictive Disorders

Advances in Microbiology Research

Advances in Industrial Biotechnology

Journal of Agronomy \& Agricultural Science

Journal of AIDS Clinical Research \& STDs

Journal of Alcoholism, Drug Abuse \& Substance Dependence

Journal of Allergy Disorders \& Therapy

Journal of Alternative, Complementary \& Integrative Medicine

Journal of Alzheimer's \& Neurodegenerative Diseases

Journal of Angiology \& Vascular Surgery

Journal of Animal Research \& Veterinary Science

Archives of Zoological Studies

Archives of Urology

Journal of Atmospheric \& Earth-Sciences

Journal of Aquaculture \& Fisheries

Journal of Biotech Research \& Biochemistry

Journal of Brain \& Neuroscience Research

Journal of Cancer Biology \& Treatment

Journal of Cardiology \& Neurocardiovascular Diseases

Journal of Cell Biology \& Cell Metabolism

Journal of Clinical Dermatology \& Therapy

Journal of Clinical Immunology \& Immunotherapy

Journal of Clinical Studies \& Medical Case Reports

Journal of Community Medicine \& Public Health Care

Current Trends: Medical \& Biological Engineering

Journal of Cytology \& Tissue Biology

Journal of Dentistry: Oral Health \& Cosmesis

Journal of Diabetes \& Metabolic Disorders

Journal of Dairy Research \& Technology

Journal of Emergency Medicine Trauma \& Surgical Care

Journal of Environmental Science: Current Research

Journal of Food Science \& Nutrition

Journal of Forensic, Legal \& Investigative Sciences

Journal of Gastroenterology \& Hepatology Research

Journal of Gerontology \& Geriatric Medicine
Journal of Genetics \& Genomic Sciences

Journal of Hematology, Blood Transfusion \& Disorders

Journal of Human Endocrinology

Journal of Hospice \& Palliative Medical Care

Journal of Internal Medicine \& Primary Healthcare

Journal of Infectious \& Non Infectious Diseases

Journal of Light \& Laser: Current Trends

Journal of Modern Chemical Sciences

Journal of Medicine: Study \& Research

Journal of Nanotechnology: Nanomedicine \& Nanobiotechnology

Journal of Neonatology \& Clinical Pediatrics

Journal of Nephrology \& Renal Therapy

Journal of Non Invasive Vascular Investigation

Journal of Nuclear Medicine, Radiology \& Radiation Therapy

Journal of Obesity \& Weight Loss

Journal of Orthopedic Research \& Physiotherapy

Journal of Otolaryngology, Head \& Neck Surgery

Journal of Protein Research \& Bioinformatics

Journal of Pathology Clinical \& Medical Research

Journal of Pharmacology, Pharmaceutics \& Pharmacovigilance

Journal of Physical Medicine, Rehabilitation \& Disabilities

Journal of Plant Science: Current Research

Journal of Psychiatry, Depression \& Anxiety

Journal of Pulmonary Medicine \& Respiratory Research

Journal of Practical \& Professional Nursing

Journal of Reproductive Medicine, Gynaecology \& Obstetrics

Journal of Stem Cells Research, Development \& Therapy

Journal of Surgery: Current Trends \& Innovations

Journal of Toxicology: Current Research

Journal of Translational Science and Research

Trends in Anatomy \& Physiology

Journal of Vaccines Research \& Vaccination

Journal of Virology \& Antivirals

Submit Your Manuscript: http://www.heraldopenaccess.us/Online-Submission.php 